\title{
Evasion at EJA: an historic challenge
}

\author{
FERNANDES, Ana Paula Cunha dos Santos (Brasil, Pará, Belém) ${ }^{1 *}$ \\ OLIVEIRA, Iranildo da Silva (Brasil, Pará, Belém) ${ }^{1+*}$ \\ ${ }^{1}$ Universidade do Estado do Pará \\ ORCID ID: https://orcid.org/0000-0003-1934-9221* \\ ORCID ID: https://orcid.org/0000-0001-6435-2687*
}

\begin{abstract}
This article is a field research and aims to analyze what possible factors are contributing to the dropout of Education of Youth and Adults in a state school in Santa Maria do Pará. It seeks to answer: what are the possible factors that contribute to the avoidance of Education of Youth and Adults in the state school of Santa Maria do Pará? Interviews were conducted with students, teachers, a deputy principal and education specialist. The results were: absence of a curriculum that takes into account the specificity of the public of the Education of Youth and Adults; lack of safety in the teaching environment and in its locality; lack of projects that serve as an attraction for students; teachers more committed to education; there is greater enrollment of the female audience; among others.
\end{abstract}

\section{Keywords}

Education of Youth and Adults. Evasion. Education. Pedagogical practices.

\section{Evasão na EJA: um desafio histórico}

\begin{abstract}
Resumo
Este artigo é uma pesquisa de campo e objetiva analisar quais possíveis fatores estão contribuindo para a evasão da Educação de Jovens e Adultos em uma escola estadual no município de Santa Maria do Pará. Busca-se responder à seguinte questão: quais os possíveis fatores que contribuem para a evasão da Educação de Jovens e Adultos na escola estadual de Santa Maria do Pará? Realizaram-se entrevistas com alunos, professores, uma vice-diretora e especialista em educação. Os resultados foram: ausência de um currículo que leve em consideração a especificidade do público da referida modalidade de educação; falta de segurança no ambiente de ensino e em sua localidade; falta de projetos que sirvam como atrativo para os discentes; professores mais comprometidos com a educação; maior matrícula do público feminino; entre outros.
\end{abstract}

\section{Palavras-chave}

Educação de Jovens e Adultos. Evasão. Educação. Práticas pedagógicas.

\section{Evasión en la EJA: un desafío histórico}

\section{Resumen \\ Este artículo es una investigación de campo y tiene como objetivo analizar qué posibles factores están contribuyendo al abandono de la Educación de Jóvenes y Adultos en una escuela estatal en Santa Maria do Pará. Se busca responder la}


siguiente cuestión: ¿cuáles son los posibles factores que contribuyen a la evasión de la Educación de Jóvenes y Adultos en la escuela estatal de la ciudad Santa Maria do Pará? Se realizaron entrevistas con estudiantes, maestros, subdirector y especialista en educación. Los resultados fueron: ausencia de un currículo que tenga en cuenta la especificidad del público de la Educación de Jóvenes y Adultos; falta de seguridad en el ambiente de enseñanza y en su localidad; falta de proyectos que sirvan como atractivos para los alumnos; profesores más comprometidos con la educación; mayor matrícula del público femenino; entre otros.

\section{Palabras clave}

Educación de Jóvenes y Adultos. Evasión. Educación. Prácticas pedagógicas.

\section{INTRODUCTION}

In this article, we seek to analyze which possible factors are contributing for school evasion at the Youth and Adult Education program (EJA, in Portuguese) in a state school in the city of Santa Maria do Pará. This article used field research and is part of the author's research for Education Master's degree. This article is thus organized: a brief preface, methodology, and lastly the section entitled "EJA, school and evasion", which presents the results concerning EJA teaching, EJA at school and school evasion at EJA.

\section{A BRIEF PREFACE}

Youth and Adult Education (EJA, in Portuguese) has raised several relevant reflections, such as: Literacy education for youth and adults (FREIRE, 2000); Teacher training for EJA and discussion about EJA curriculum (MACHADO, 2008); Legislation regarding Youth and Adult Education (UNESCO, 2008), among others. This led to questions concerning the pedagogical practices adopted by education institutions in their applicability for EJA students. Therefore, it is believed that the EJA student needs concrete and attractive pedagogical practices that can influence the process of knowledge construction in order to avoid future evasion at Youth and Adult Education programs.

Seeking to find the reasons that lead to school evasion, a question arises: what is contributing to school evasion at EJA in a state school in the city of Santa Maria do Pará? Therefore, we aim to analyze which possible factors contributed to school evasion at the 
Youth and Adult Education program in a state school in the city of Santa Maria do Pará. We highlight that the student body at this school consists of workers from different fields (construction workers, stay-at-home mothers, farm workers, among others), and most reside in the city's rural area.

According to the Curriculum Proposal for Youth and Adult Education (BRASIL, 2002, p. 87), EJA has a historical-political-social function, because its purpose is "repairing, equalizing and qualifying", so that its target audience can become citizens who are critically reflexive of their rights as opinion makers. These students noticeably need those rights, and one method to repair that is creating education opportunities, with the students as the key to the knowledge construction process, equalizing them in order to enter the workforce, achieving adequate levels and an excellent training not only in the educational field, but in every aspect, since EJA, with these functions, reveals an historic challenge.

Researching publications about that theme in the Thesis Database by the Coordination for the Improvement of Higher Education Personnel (CAPES, in Portuguese), which has dissertations and theses from Master's and Doctorate programs in Brazil since 1987, we used these descriptors: Evasion at EJA; Evasion at Youth and Adult Education; School Evasion at EJA; and EJA and Evasion. Within the results of the survey using those descriptors, only 17 out of 21 publications fit the theme.

Among the 17 publications researched, we highlight: 1) Youth and Adult Education: perspectives and evasion in the city of Cáceres-MT (LARA, 2011); 2) Youth and Adult Education and school evasion: the case of Federal Institute of Ceará, Fortaleza Campus (ROCHA, 2011); 3) Youth and Adult Education in the city of Natal: a reflection on failure and success (NOGUEIRA, 2012); 4) Youth and Adult Education: a study on interrupted school careers (SANTOS, 2012).

\section{METHODOLOGY}

The methodology used in this study had an investigative nature, through field research. Fonseca (2002, p. 20, our translation) reports that "field research is characterized by investigations in which, besides bibliographic and/or document 
research, data collection is carried out with other people, through different types of research".

The research took place in the city of Santa Maria do Pará, in the northeast of the state of Pará, approximately $100 \mathrm{~km}$ from Belém (the state capital). The city has a population of 23,033 , according to the 2010 IBGE census, and an alarming index of $26.1 \%$ of illiterate people who are 15 years old or older within that population. The school is located in the city center, but is considered periphery, and serves students from the city's rural and urban areas.

Analyzing the school's Political-Pedagogical Project (PPP) from 2012, the most recent one made available by the school, we saw that the school consists of ten classrooms, the principal's office, an administrative office, a teacher's room, a library, a computer room, a cleaning supply cupboard, a pantry, a cafeteria, an indoors sports hall, a kitchen, a service area, a multipurpose room, a pedagogical coordination room, two staff restrooms, four student restrooms (two male and two female) and two accessible restrooms. The school's staff in 2012 consisted of 51 people, among teachers, technical team, school management, guards and janitors, with 46 hired employees and five temporary employees.

Data collection took place on five days: November 28th and December 1st, 4th, 5th and 10th, 2014. Interviews with students, teachers, one deputy principal and education specialist were carried out in the night shift, and interviews with the principal and deputy principal, in the morning shift. In 2014, the EJA program consisted of: one group of 1 st Level (1st and 2nd grade); one group of 2 nd Level (3rd and 4th grade); two groups of 3rd Level (5th and 6th grades); and one group of 4th Level (7th and 8th grade). In total, 203 (two hundred and three) students enrolled in 2014.

Table 1 - Students enrolled in EJA in 2014

\begin{tabular}{ccccccc}
\hline Situation & $\mathbf{1}^{\text {st }}$ Level & $\mathbf{2}^{\text {nd }}$ Level & $\mathbf{3}^{\text {rd }}$ Level "A" & $\mathbf{3}^{\text {rd }}$ Level "B" & $\mathbf{4}^{\text {th }}$ Level & Total \\
\hline Enrolled & 25 & 30 & 50 & 45 & 53 & 203 \\
\hline $\begin{array}{c}\text { Attending } \\
\text { school }\end{array}$ & 10 & 08 & 09 & 15 & 21 & 63 \\
\hline
\end{tabular}

Source: Compiled by the authors based on data collected at the school (2014). 
The data shown on table 1 represent enrolled students since the beginning of the school year (January) until the end of the year (December), i.e., from January to December, 140 of the 203 students dropped out.

In order to safeguard the identity of the teachers who were interviewed, their names were replaced by $\mathrm{P} 1, \mathrm{P} 2, \mathrm{P} 3 \ldots$ etc., since the school has a small number of professionals working in the night shift, when the EJA program is run.

The following information resulted from answers by interviewees concerning students and, for better visualization, were collected in a table.

Table 2 - Student distribution according to age and gender

\begin{tabular}{ccc}
\hline Age & Male & Female \\
\hline $\mathbf{1 5 - 2 0}$ & 12 & 10 \\
$\mathbf{2 1 - 3 0}$ & 03 & 06 \\
$\mathbf{3 1 - 4 0}$ & - & 03 \\
$\mathbf{4 1}$ or older & 02 & 02 \\
\hline Total & 17 & 21
\end{tabular}

Source: Compiled by the authors based on data collected at the school (2014).

There are more male students in the 15 to 20 -year-old age range, but overall there are more female students. The age range with fewer students is that of 41 years of age or older.

Table 3 - Sample of interviewees according to the questions posed to learn about the public that attends the school researched

\begin{tabular}{ccccc}
\hline Questions & \multicolumn{2}{c}{ Men } & \multicolumn{2}{c}{ Women } \\
\cline { 2 - 5 } Work & Sim & Não & Sim & Não \\
$\begin{array}{c}\text { Married } \\
\text { Children }\end{array}$ & 17 & - & 13 & 08 \\
$\begin{array}{c}\text { Family income up to one } \\
\text { minimum wage }\end{array}$ & 04 & 13 & 05 & 16 \\
$\begin{array}{c}\text { Family income greater than one } \\
\text { minimum wage }\end{array}$ & 07 & 14 & 08 & 13 \\
Welfare & 08 & 08 & 06 & 15 \\
\hline
\end{tabular}

Source: Compiled by the authors based on data collected at the school (2014).

We can notice that all men interviewed work, as well as more than half of the women. Generally, women already have children, jobs and take care of the home, constituting double or triple shifts. Although all men answered that they work, most of them are also on welfare, a result similar to the women who get government assistance.

Educação \& Formação, Fortaleza, v. 5, n. 13, p. 79-94, jan./abr. 2020

DOI: https://doi.org/10.25053/redufor.v5i13.990

http://seer.uece.br/redufor 


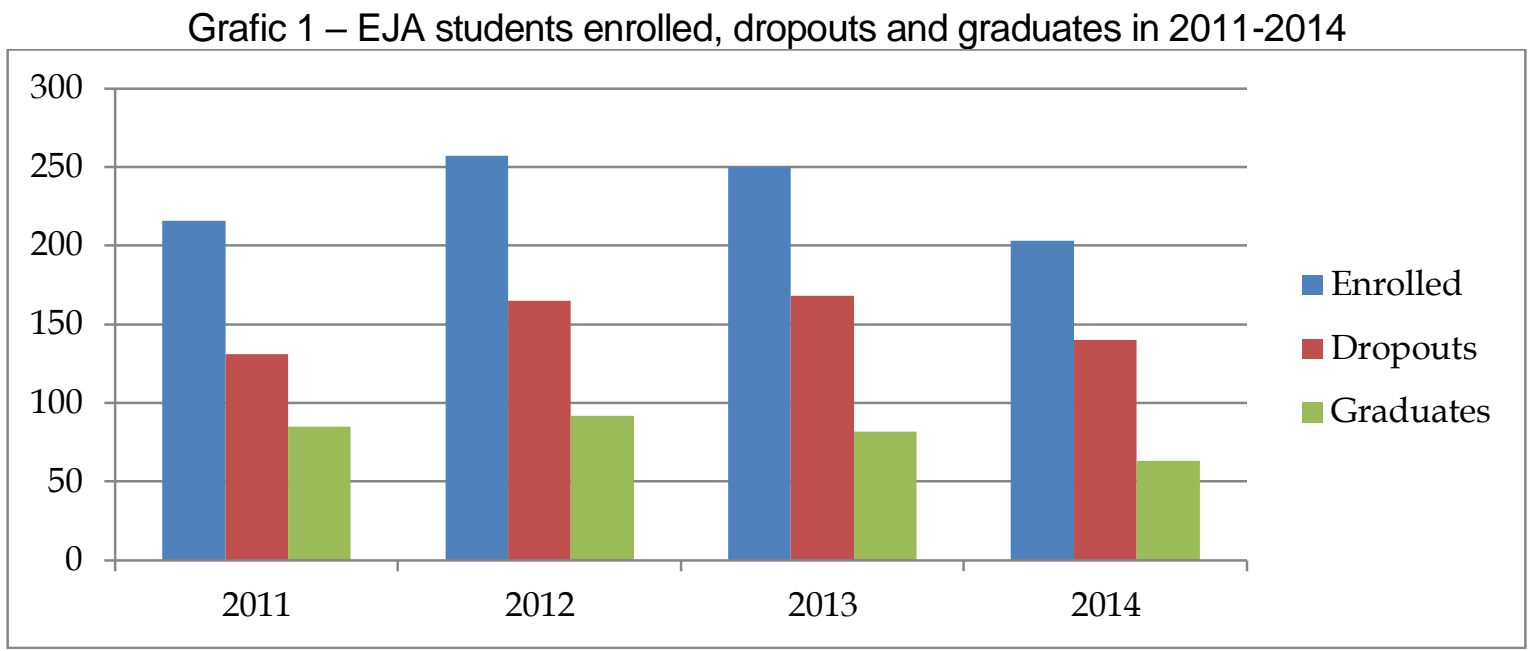

Source: Compiled by the authors based on data collected at the school (2014).

According to data collected at the research locus, it becomes clear that the issue of evasion at the school researched did not begin at the time of research, but is a continuous and expanding process of evasion perpetuated through the years.

Table 4 - School evasion in EJA in 2011-2014

\begin{tabular}{lc}
\hline Year & Dropout rate \\
\hline $\mathbf{2 0 1 1}$ & $60,7 \%$ \\
$\mathbf{2 0 1 2}$ & $64,4 \%$ \\
$\mathbf{2 0 1 3}$ & $67,2 \%$ \\
$\mathbf{2 0 1 4}$ & $68,9 \%$ \\
\hline
\end{tabular}

Through these data, the alarming numbers of school evasion are noticeable, becoming an historic process within this education institution's scenario, because probably school evasion in EJA did not begin in 2011, the first year on Table 4, risking the future of the students and of the program in the school researched.

The questionnaire for the students consisted of 13 questions, among multiplechoice and essay questions, in order to get an overview of the public assisted by the school. The education professionals were asked six essay questions, aiming to analyze their knowledge about EJA. The student questionnaire had questions concerning: work; family life; children; income from government assistance; family income of up to one minimum wage; family income greater than one minimum wage; school evasion after previous return to school; economic situation detrimental to school; work as a hindrance to school; family support toward education; methodology used in the classroom; 
encouragement found in school to continue studying; what could improve in school to attract the students' attention.

The questionnaire aimed at teachers (including education specialist and school management) consisted of six essay questions aiming to gather information on the professionals' knowledge about EJA: How is the EJA curriculum organized? Does the curriculum guarantee work/education balance for students? How is the curriculum materialized in pedagogical practices? Are school evasion rates high at the school researched and what contributes to that? What methods are used to reduce evasion? What long-term projects does the school propose to minimize the impacts of school evasion?

\section{YOUTH AND ADULT EDUCATION, SCHOOL AND EVASION}

In this section, among the topics discussed, we highlight: teaching in EJA, EJA at school, and evasion at/from EJA. The 2014 Brazilian Basic Education Annual Report indicates a dropout rate of $4.1 \%$ for the last year of Primary School and of $11.6 \%$ for the first year of High School in 2012, in Brazilian schools. These young people seek to compensate some of that time at Youth and Adult Education programs. The same report shows that, in 2012, age-grade distortion rates reached 22\% in Primary School and 31.1\% in High School.

EJA is a modality of Basic Education, and among educational priorities is the guarantee of Basic Education for those who didn't have access to it at the expected age or who didn't graduate (BRASIL, 2010, p. 8), which is restated in Law N. 9.394/1996 (LDB), in Article 37: "Youth and Adult Education will be destined for those who didn't have access or continuity of education during Primary and High School at the expected age" (our translation).

The fact that a person, young or adult, seeks school to continue or begin their education already shows a change in their ideas about their societal status, seeing education as an opportunity to change their financial and social status. According to Freire (1992, p. 41), this public's pursuit of school derives from a desire to decode reading and writing, but he interjects that this event, as a consequence, awakens critical thinking. Within that perspective, the school must be willing to seek strategies 
to help the students' development in all fields of knowledge, proposed through attractive and diverse classes. From that viewpoint, Gadotti (2009, p. 17, our translation) argues that:

Education is necessary for the survival of human beings. In order to avoid creating everything again, they must internalize the culture, what humankind has already produced. If that was important in the past, it is even more decisive nowadays, in a society based on knowledge.

In this angle, the EJA student has a wider knowledge of the world, if compared to the student in regular school, and seeks the interaction with the teacher at school in order to improve that knowledge in an educational perspective, embracing the knowledge that each student brings and designing classes based on their everyday life. This way, students will feel like part of the learning process, because they will be constructing knowledge. Within this perspective, Freire (1967, p. 43, our translation) argues that:

Through human relationship with reality, a result of being with it and in it, through acts of creation, recreation and decision, people boost their world. Dominate reality. Humanize it. Add to it something they created themselves. Temporalize geographical spaces. Make culture. It is also this game of the relationship between humans and the world and among humans themselves, challenging and responding to that challenge, changing, creating, that doesn't allow immobility, except in terms of relative preponderance, neither of societies nor cultures. And as they create, recreate and decide, historical eras are made. It is also creating, recreating and deciding that humans must participate in those eras.

Youth and Adult Education is built within its specificities, with a diverse public, rich in knowledge and from different cultures and social classes, including Indigenous, Black and white people, Evangelical and Catholic people, among others, all of whom share an objective, seeking to identify themselves and to stay in a space that, for many, wasn't part of their routine, i.e., the classroom.

Youth and Adult Education has a fundamental role in the historic-social construction of the students' lives, considering education's transformative role, because the more contact students have with literacy, the more they become independent and critical. Therefore, it is the teacher's responsibility to select and organize lessons that stimulate the practice of critical thinking, so that students can have individual perceptions of social events. 
Developing criticality in EJA students is to empower them as citizens with rights, a fundamental role of schools and especially of teachers, because to turn those students into political beings, in the true sense of the expression, is to free them from the binds historically created by a dominant class. Arroyo (2002, p. 79, our translation) argues that "[...] that is the educational process to which the bourgeoisie and the State react, trying to deny, fragmentize, confuse it". Strategies for the formation of conscience must be considered by education professionals in order to guide the student in that direction, besides contributing to their permanence in the school environment.

In the last decades, Youth and Adult Education has been getting more national and international attention, because, in order to eradicate illiteracy, these programs need to be better examined. With this in mind, the Hamburg Declaration (UNESCO, 1999, p. 20, our translation) states that:

4. [...] The perspective of learning throughout life demands, in turn, complementarity and continuity. The contribution of Adult Education and Continued Education is of paramount importance for the creation of a tolerant and educated society, for socioeconomic development, for the eradication of illiteracy, for the decrease of poverty and for environmental preservation.

We notice that the knowledge brought by the EJA student can become a key point in the learning process, but, as mentioned before, there were no mentions of EJA in the PPP constructed by the education institution researched. Within this perspective, Fernandes and Gonçalves (2013, p. 47, our translation) assert that "EJA has been identified as popular education, therefore it has meaning. This teaching modality has been wrongly understood as carefree action". From the same viewpoint, Freire (1987, p. 49, our translation) concludes that:

This practice entails, consequently, proximity with popular masses, not to present them with a 'savior' message, in the shape of content to be filed, but to know, through dialogue with them, not only their objectivity, but their conscience of that objectivity; the different levels of perception of themselves and of the world where they are.

Throughout history, education has been considered a way to maintain power. Concerning that point of view, Arroyo (2002) ponders that the dominant elite always controlled education so that the people wouldn't be enlightened about their function and 
social position and question their rights, offering a dualistic education, within the notion of a reproductive device for the State. However, the EJA student's desire, according to Lara (2011, p. 66, our translation) is always to achieve "[...] better work positions, greater quality of life and better conditions to interact with other people and with the globalized world where they live".

\subsection{Teaching in EJA}

Even with all the evolution in Law that assuaged how EJA has been approached, we arrived at the 21 st century with problems from years ago. About that, P7 states:

I think that teaching in EJA should be different, because students are already tired when they get to school (many of them work) should be more attractive, interesting. We should use technology for our advantage. But SEDUC doesn't provide that, we don't have courses, only demands. (our translation).

The statement by professional P7 shows some concern about necessary training to work with Youth and Adult Education, besides reporting the lack of partnerships for continued education, since only through adequate training can teachers socialize their knowledge with students in a distinguished way. According to Arroyo (2002, p. 78, our translation), this happens because:

[...] the right to education, the advancements by working classes in the construction of knowledge, culture and class identity are still systematically denied, repressed and, while possible, unstructured, for being radically antagonistic to capital movement.

With the knowledge acquisition promoted by education, the student will become self-sufficient in their own thoughts, questioning what is imposed to them, with broad vision of social issues, besides the desire to reach higher levels, risking the stability of the social pyramid.

Professional training is unquestionable when it comes to diverse possibilities in the learning process to offer those who seek this teaching modality, and one must be prepared to work with Youth and Adult Education. Machado (2010, p. 115, our translation) considers that: 
The pedagogical challenge of acknowledging our insurmountable incompleteness conflicts with the 'academic' logic, which convinces us of a false idea of truth that can be caught and locked in a course, in training, or how, unfortunately, many people still refer to it, a 'recycling' course.

The aforementioned author discusses the training of education professionals, with training and qualification being necessary for all professionals, always aiming to expand their knowledge in the chosen field.

\subsection{EJA at school}

Youth and Adult Education is a modality of social achievement, but evasion has contributed to the emptying of classrooms at the school researched. Analyzing the document that guides the actions of education institutions, the Political-Pedagogical Project (PPP), responsible for directing activities of modalities offered at the school, there were no paragraphs including EJA in school activities or goals that the institution should achieve, like the issue of school evasion. The school's latest PPP is from 2012 and doesn't include guidelines for EJA, which evidences that the program isn't a commitment for school management, since all projects described in the PPP contemplate regular grades.

\subsection{Evasion at/from EJA}

School evasion is one of the greatest hindrances in the development of the young or adult student, who are led to drop out of school due to different factors (both internal and external to school). This issue must be handled seriously, so that future student groups or even the Youth and Adult Education program itself isn't canceled for lack of students and/or projects that strive for the guarantee of permanence in the education institution. Nogueira (2012) adds that the problem of evasion at Youth and Adult Education isn't local or regional, but a national and historic problem.

We asked students and education professionals about the reasons why students drop out of EJA. According to the education professionals interviewed, the reasons are: lack of security; school location; school management; teachers; lack of projects that evoke students' interest to stay in the school environment; jobs; pregnancy; and the students' lack 
of interest. What must be highlighted is the fact that $80 \%$ of the professionals interviewed pointed to lack of security as the main reason for the emptying of classrooms, and $50 \%$ report that school location is one of the main reasons.

The places farther from the city center receive, consequently, less attention from the public administration and serve public with lower income. That, added to poor public illumination and lack of police, results in increased criminality.

Students mention similar reasons. In their opinion, the factors that cause students to drop out are: lack of security; lack of interest from students; school management respect toward students; teachers more committed to education; projects that evoke students' interest to stay in the school environment. Those reasons can be demonstrated thus: $41.8 \%$ of students reveal that lack of security contributes to student evasion at this school, in the EJA program; $10.52 \%$ state that school management should be more respectful when dealing with students; $10.52 \%$ report that teachers need to show more interest toward students; but 37,16\% didn't know or didn't have an opinion about the reasons for student evasion.

Lack of security is the most aggravating factor that directly contributes for students to drop out of school, due to its location in the periphery, far from the eyes of public administration, since students have reported robberies nearby and the lack of public illumination contributes to those crimes. Santos (2012, p. 102, our translation) concludes that "school exclusion is accentuated in the root of social exclusion marked by the contradiction of classes in a similarly unequal economic model", since: "Adult Education practices originated in the midst of civil society, in the 'gaps' of the Brazilian educational system. The main characteristics of government actions for EJA in the 20th century were assistance, populist and compensatory policies" (ROCHA, 2011, p. 24, our translation:

Among so many social issues that somehow interfere/prevent the EJA students from acquiring education, when they seek education institutions of their own volition in order to improve their knowledge, the least that could be offered to them is quality education, aiming at the higher levels of knowledge. 


\section{FINAL CONSIDERATIONS}

This study's objective was to analyze, through a field research, the factors that contribute to school evasion at EJA at a state school in Santa Maria do Pará. The theme "Youth and Adult Education" highlights the issue of school evasion, even with more flexible laws encouraging enrollment and permanence at the institutions. Among the results, we can highlight: In 2014, only 63 students finished the school year. There is emphasis on the $68.96 \%$ rate of student evasion.

Between 2011 and 2014, there were more students enrolled and students who graduated, 203 and 63, respectively. In 2012 and 2013 there was a high number of students enrolled, but also a high number of students who dropped out. Evasion at EJA has been noticed throughout the years in the school records and the school census. The rate of evasion, between 2011 and 2014, increased approximately $8.2 \%$.

About teaching in EJA, the teacher emphasizes that it could be more attractive, distinguished and interesting if technology were used in their favor and highlights the lack of continued education by the State Secretariat for Education. EJA isn't included in the school's activities or goals in the PPP. This absence suggests the invisibility of this modality in the actions of school management.

Among factors that contribute to evasion listed, $80 \%$ of teachers point to the lack of security and $50 \%$ mention the school location. The students' answers were: a) $41.8 \%$ mentioned lack of security; b) $10.52 \%$ mentioned the lack of respect shown to students by school management; c) $10.52 \%$ mentioned the lack of interest of teachers toward students; and d) $37.16 \%$ didn't have an opinion or didn't know how to answer. We emphasize that for both teachers and students, the most significant factor was lack of security. However, the criticisms and remarks about the school, teachers, school management and teaching cannot be ignored.

\section{REFERENCES}

ARROYO, M. G. O direito do trabalhador à educação. In: GOMES, C. M. et al. (Org.). Trabalho e conhecimento: dilemas na educação do trabalhador. São Paulo: Cortez, 2002. p. $75-92$. 
BRASIL. Lei o 9.394, de 20 de dezembro de 1996. Estabelece as Diretrizes e Bases da Educação Nacional. Diário Oficial [da] República Federativa do Brasil, Poder Executivo, Brasília, DF, 21 dez. 1996.

BRASIL. Parecer CNE/CEB n. 6/2010. Reexame do Parecer CNE/CEB, que institui Diretrizes Operacionais para a Educação de Jovens e Adultos - EJA, nos aspectos relativos à duração dos cursos e idade mínima para ingresso nos cursos de EJA; idade mínima e certificação nos exames de EJA; e Educação de Jovens e Adultos desenvolvida por meio da Educação a Distância. Diário Oficial [da] República Federativa do Brasil, Poder Executivo, Brasília, DF, 7 abr. 2010.

BRASIL. Proposta Curricular para a educação de jovens e adultos: segundo segmento do ensino fundamental: $5^{\mathrm{a}}$ a $8^{\mathrm{a}}$ série: introdução. Brasília, DF: Ministério da Educação, 2002.

FERNANDES, A. P. C. S.; GONÇALVES, T. G. Alunos com deficiência na Educação de Jovens e Adultos: e a formação para os professores? In: RESENDE DA COSTA, M. P. (Org.). Educação especial: sugestões de recursos para os ambientes educacionais inclusivos. São Carlos: Pedro \& João, 2013. p. 29-50.

FONSECA, J. J. S. Metodologia da pesquisa científica. Fortaleza: UEC, 2002. Apostila.

FREIRE, P. Educação como prática da liberdade. Rio de Janeiro: Paz e Terra, 1967.

FREIRE, P. Pedagogia da esperança: um reencontro com a pedagogia do oprimido. Rio de Janeiro: Paz e Terra, 1992.

FREIRE, P. Pedagogia da indignação: cartas pedagógicas e outros escritos. São Paulo: Unesp, 2000.

FREIRE, P. Pedagogia do oprimido. 17. ed. Rio de Janeiro: Paz e Terra, 1987.

GADOTTI, M. Educação de adultos como direito humano. São Paulo: Paulo Freire, 2009.

IBGE - Instituto Brasileiro de Geografia e Estatística. Censo 2010. Rio de Janeiro: IBGE, 2011.

LARA, P. J. Educação de Jovens e Adultos: perspectivas e evasão no município de Cáceres-MT. 2011. 98 f. Dissertação (Mestrado Acadêmico em Educação) - Programa de Pós-Graduação em Educação, Universidade do Oeste Paulista, Presidente Prudente, 2011.

MACHADO, M. M. (Org.). Formação de educadores de jovens e adultos. Brasília, DF: Secadi: Unesco, 2008.

MACHADO, M. M. Processos de formação de educadores de jovens e adultos: os desafios políticos e pedagógicos da formação de educadores de EJA no Brasil. In: 
DALBEN, Â. I. L. F. et al. (Org.). Convergências e tensões no campo da formação e do trabalho docente. Belo Horizonte: Autêntica, 2010. p. 100-121.

NOGUEIRA, A. A. S. Educação de Jovens e Adultos na cidade de Natal: uma reflexão sobre insucesso e sucesso. 2012. 68 f. Dissertação (Mestrado Acadêmico em Educação) - Programa de Pós-Graduação em Educação, Universidade Federal do Rio Grande do Norte, Natal, 2012.

ROCHA, W. M. Educação de Jovens e Adultos e a evasão escolar: o caso do Instituto Federal do Ceará, campus de Fortaleza. 2011. 157 f. Dissertação (Mestrado Acadêmico em Educação) - Programa de Pós-Graduação em Educação, Universidade Federal do Ceará, Fortaleza, 2011.

SANTA MARIA DO PARÁ. Projeto Político-Pedagógico. 2012.

SANTOS, V. P. Educação de Jovens e Adultos: um estudo sobre trajetórias escolares interrompidas. 2012. 167 f. Dissertação (Mestrado Acadêmico em Educação) Programa de Pós-Graduação em Educação, Pontifícia Universidade Católica de Goiás, Goiânia, 2012.

TODOS PELA EDUCAÇÃO. Anuário Brasileiro da Educação Básica. São Paulo, Moderna, 2014.

UNESCO - Organização das Nações Unidas para a Educação, a Ciência e a Cultura. Declaração de Hamburgo: agenda para o futuro. Brasília, DF: Sesi/Unesco, 1999.

UNESCO - Organização das Nações Unidas para a Educação, a Ciência e a Cultura. Alfabetização de jovens e adultos no Brasil: lições da prática. Brasília, DF: Unesco, 2008.

Ana Paula Cunha dos Santos Fernandes (Brasil, Pará, Belém)

Universidade do Estado do Pará (UEPA)

PhD Professor at the State University of Pará (UEPA) with undergraduate and postgraduate education. Coordinates the Special Education Study and Research Group in the Amazon (GEPEEAm).

Lattes: http://lattes.cnpq.br/8441289836978380.

E-mail: docenteapf@gmail.com.

\section{Iranildo da Silva Oliveira (Brasil, Pará, Belém)}

Universidade do Estado do Pará (UEPA)

Master student in the Graduate Program in Education at the State University of Pará (UEPA), in the Teacher Training Line and Pedagogical Practices. Graduated in Pedagogy. Specialist in Specialized Educational Attendance. Active in the Special Education Study and Research Group in the Amazon (GEPEEAm).

Lattes: http://lattes.cnpq.br/5678711232049629.

E-mail: iranildo_silva_oliveira@hotmail.com.

Educação \& Formação, Fortaleza, v. 5, n. 13, p. 79-94, jan./abr. 2020

DOI: https://doi.org/10.25053/redufor.v5i13.990

http://seer.uece.br/redufor 


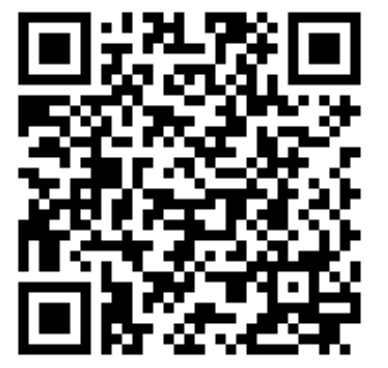

Received on February 5, 2019.

Accepted on July 1, 2019. 